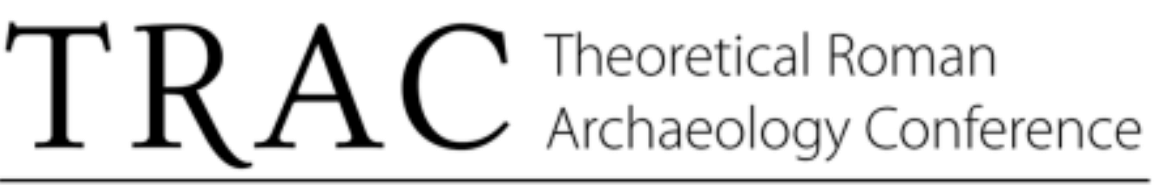 \\ www.trac.org.uk
}

\section{Paper Information:}

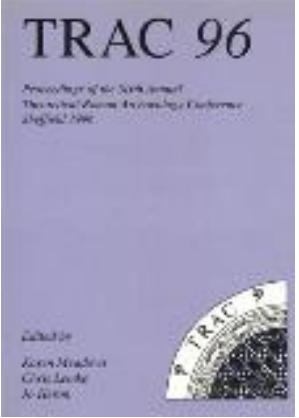

Title: Pooling Resources - The Use of Water for Social Control in the Roman Empire

Author: S. Ellis

Pages: $144-150$

DOI: http://doi.org/10.16995/TRAC1996 144150

Publication Date: 11 April 1997

\section{Volume Information:}

Meadows, K., Lemke, C., and Heron, J. (eds) 1997. TRAC 96:

Proceedings of the Sixth Annual Theoretical Roman Archaeology Conference, Sheffield 1996. Oxford: Oxbow Books.

\section{Copyright and Hardcopy Editions:}

The following paper was originally published in print format by Oxbow Books for TRAC. Hard copy editions of this volume may still be available, and can be purchased direct from Oxbow at http://www.oxbowbooks.com.

TRAC has now made this paper available as Open Access through an agreement with the publisher. Copyright remains with TRAC and the individual author(s), and all use or quotation of this paper and/or its contents must be acknowledged. This paper was released in digital Open Access format in April 2013. 


\title{
16. Pooling Resources - The Use of Water for Social Control in the Roman Empire
}

\author{
by $S$. Ellis
}

\section{Introduction}

Water has always been a vital commodity to the peoples of the Mediterranean with their hot summers. In many Mediterranean countries it is no exaggeration to say that control of a water source is control of life. A strong spring can be a motive for founding a city, while a dried up spring can be the motive for abandoning a settlement. At such an intuitive level it would seem inevitable that Roman control of water power was a means of asserting effective control over its citizenry.

The Romans expended enormous effort in supplying water to their cities. For example, the Zaghouan aqueduct which brought water to Carthage ran for over $90 \mathrm{~km}$ (Hodge 1992:346), and siphons were used to pass water across valleys as at Aspendos (Hodge 1983, 1992). A further example of this effort can be found in the construction of great arches, such as those of the Pont du Gard which crossed ravines. For local people these mighty engineering projects would have been impressive symbols of Roman power, and of their superior technical knowledge. Such engineering works, and the buildings to which many of them led - public fountains and baths - were symbols of conspicuous consumption. They identified Roman cities as places where water flowed freely, like rivers of gold.

Such an intuitive theory must be tested against more specific evidence. To begin with the growth of imperial control of the water supply in the City of Rome from the reign of Augustus to the beginning of the second century AD may be examined.

\section{Rome}

Millar (1977:193) describes growing imperial control of the water supply as documented in Frontinus. Originally the building of aqueducts was as much an act of private munificence as the erection of any public building by an individual. However, when Agrippa worked on the Aqua Julia and Tepula in $33 \mathrm{BC}$, and the Aqua Virgo in $27 \mathrm{BC}$, he formed a special work force. This work force, together with Agrippa's other responsibilities and properties, were left to Augustus, who placed them under the control of the state. Under Claudius, the size of the imperial water workforce was increased and the senatorial curator was replaced by an imperial freedman - the procurator aquarum. In order for private citizens to obtain water from the aqueducts they had to petition the emperor (see above). The substantial sums of money received from water rights petitions originally went to the people, but later were diverted to the imperial chest by Domitian. 
Following this discussion, Millar (1977) goes on to note the similar imperial expropriation of the right to hold games, but he does not, however, draw out the comparison. In social terms, both services fulfilled the same function. The games provided the main source of the city's entertainment, and an opportunity for the emperor to receive feedback on a grand scale. The aqueducts, in feeding the public baths, were the mainstay of the city's social life, maintaining its business meetings and the source of informal political discussion.

The system of water supply also resembled the corn dole, the annona. The annona kept the people contented thereby avoiding civic disturbances. The use of aqueducts allowed the government to keep the citizens amused, by the provision of public baths, fountains and other diversions. The emperor provided both food and water for his people.

It would thus seem possible to claim that the imperial take-over of the water supply was a political, as well as an economic decision. Coinage was often used as propaganda to demonstrate imperial achievements in providing for the citizenry. Explicit images of Annona are common in the early imperial period, and representations of many other deities imply abundance and imperial largesse. The provision of water by aqueduct, though allowing easy illustration of a similar theme, is rarely represented. The only clear image of an aqueduct is a Republican denarius of $56 \mathrm{BC}$ by L. Marcus Phillipus showing an aqueduct, and it is explicitly labelled 'Aqua Marc(ia)'. Even here the equestrian statue on top of the aqueduct may show some confusion with a triumphal arch (Harlan 1995:94-9). Personification of rivers on coins has also been shown to commemorate the completion of aqueducts at Ephesus and Pergamon (Garbrecht 1991).

It would thus appear that the intuitive argument with which we began, that water provides a means of control of the local people, can be supported by an historical argument that the emperors used the control of Rome's water supply to control the city's social life. This 'control' should not be thought of in too literal a sense. Public baths, for example, were not a hotbed of political intrigue manned by imperial spies. Nevertheless, the emperors knew that the baths were major centres for business deals. In providing the baths the emperors were able to create identifiable places where local financial and political dealings would operate.

The emperor expropriated the public water supply for the city of Rome, and was able to use it to reduce public discontent, and emphasise his munificence. He also used his control of public water to demonstrate his power over the individual. The emperor's express permission was required for a private individual to tap into the public water supply (Millar 1977). One of Frontinus' main concerns was to prevent this happening illegally. He clearly believed it was immoral for private citizens to take water from the aqueduct (2.75-6). It is unclear how much he believed it was a crime against the people, or the emperor. In practice the emperor's permission to tap the public supply was often asked and granted. Both Statius (Silvae 3.1.61-4) and Martial (9.18) were successful in this and dutifully celebrated in poetry. In another poem Martial (8.66.7-8) had lamented his fate in being stuck in a third floor rented flat without running water. Millar (1977) mentions how the substantial revenue from such petitions was, at least in principle, due to the people.

Obtaining a water permit was regarded as an achievement, but does not seem to have been unduly difficult. At least there seems to be no evidence for access to water being refused for political reasons. Control of water at the general and individual level was thus operated in a 'controlled' way, but not as a direct instrument of power politics. 


\section{The Provinces}

The previous section has demonstrated how in the city of Rome, the emperors were able to use the water supply as a means of social control. It is now necessary to investigate the position in the Roman provinces.

The emperor clearly could not keep a direct eye on all that was going on in the provinces, and depended on the provincial governors. As governor of Bithynia under Trajan, Pliny the Younger consults the emperor about the building of an aqueduct for Nicomedia, and asks the emperor for an engineer (Letter 10.37). Sherwin-White (1966:593) suggests that Pliny makes a habit of explicitly asking the emperor's permission for building works that involve a contribution from municipal funds. This was a rule later made explicit under Antoninus Pius (Digest 50.10.3,6-7).

It would seem then that Roman emperors, at least from the second century AD when the majority of provincial aqueducts were constructed, were able to keep a control on their construction. However, the sources quoted in the previous paragraph indicate that this rule was applied to all public buildings financed by public money. The purpose of the rule was fiscal, to prevent the frittering away of public money on ill-considered projects.

Referral to the emperor might be avoided if private finance was obtained. Leveau (1991:153-4) considers that even the richest senatorial patron would rarely have enough resources to finance a complete monumental stone aqueduct. Prior to the request by Pliny $(10.37)$ for help in the construction of the Nicomedia aqueduct, the town had already wasted three and a half million sesterces on a faulty scheme. According to Leveau (1991:153) this would only be enough for some two kilometres of channel.

Even if a town was able to undertake aqueduct construction without public finance, it would probably still need help from the authorities. Aqueduct building was precision engineering and required a high level of technical expertise. Pliny clearly believed that it was not possible to find a suitable engineer in Bithynia, and repeatedly asks the emperor to send someone with experience in building aqueducts or canals (Letters 10.37, 10.41, 10,61). Trajan expresses doubts about the lack of skills in Bithynia, but reluctantly asks Pliny to see if the governor of Moesia Inferior can help (10.62).

The most obvious source of qualified engineers was, of course, a province with an active garrison like Moesia Inferior. The dangers of trying to proceed without skilled help, and the difficulties of retaining a military engineer were well learned by Saldae in Mauretania Caesariensis. An engineer of Legio III Augusta, Nonius Datus, was seconded to the governor's staff to draw up the project around $\mathrm{AD}$ 137. Having returned to his legion he was recalled at the end of the 140 s to sort out technical difficulties in the project. In the following decade the aqueduct workers were digging a tunnel by the normal Roman practice of starting at both ends, when they lost their direction. Nonius Datus was recalled again, narrowly survived capture by brigands, and the project was finally completed successfully (CIL 8.2728).

This evidence is sufficient to demonstrate that, in order for a monumental aqueduct to be successfully completed, some form of state help in the form of technical, or financial assistance would normally be needed. The evidence indicates that state authorisation of aqueduct construction was, at least partly, a means of ensuring that money was wisely spent. In order to decide whether state intervention in aqueduct construction was also motivated by desire for social control it is necessary to re-examine how the water from provincial aqueducts was used. 


\section{The Nature of the Supply}

The comparison between the annona and the water supply drawn above conceals a fundamental misconception to which we have already alluded: aqueducts were generally destined for public buildings rather than private houses. The precise destinations of aqueducts cannot often be determined, and many have multiple outlets, but it would seem that the major part of the supply went to public baths (Hodge 1992:48-9). Aqueducts did not provide the primary supply to private houses (Schwartz 1981:52; Thébert 1988:330; Shaw 1991:66-73; Hodge 1992:48-9). Before an aqueduct supply was introduced the inhabitants had to rely on wells and cisterns. These continued to provide the main source of water for the majority of householders.

Aqueducts might feed public fountains and drinking troughs. The latter might be plain stone tanks, but from at least the early second century AD public fountains were identified as nymphaea and took on an increasingly monumental aspect with up to two storeys of niches containing statues (see for example, the fountain of Trajan at Ephesus - Akurgal 1978:165; Side-Mansel 1978; or Tipasa - Aubert 1974). This monumentalisation indicates that provision of water to the lesser public is of less importance than the self aggrandisement of the aristocrat who financed the construction. A two storey marble-lined fountain filled with statuary was a more conspicuous display of wealth and liberality on the part of the donor, than an invitation for the poorer citizen to use it for their daily supply of water.

The water supply of a major Roman city was therefore constructed by the elite and substantially used by them in conspicuous displays of luxuria at the public baths and the nymphaea. Whereas the annona demonstrably had an alimentary function (even if it conferred a certain social status as well), the public water supply was mainly used for bathing. The fact that water could be used in such a wanton fashion must have seemed quite remarkable to rural provincials.

\section{The Limitations of Roman Water Technology}

A further indication that the prime function of Roman water supplies was for the purposes of the elite, can be seen in the technical limits of Roman control over the supply. An aqueduct flow could not simply be turned off. To close off the channel was simply to invite the flow to back up. Such problems were of course offset by directing the aqueduct through a large public cistern or lacus which allowed for variations in demand or supply, filling or emptying the reservoir. Nevertheless when the flow of the aqueduct ceased such cisterns could quickly run dry. Equally when there was a major surge in supply there could be little option but to let the public fountains overflow. Frontinus was very careful to monitor such overflows and the use of surplus water from the fountains of Rome.

The castellum divisorium is often identified as a mechanism for controlling the water supply to match demand. Elaborate systems of gates at Pompeii and Nîmes (Hauck \& Novak 1988) have been suggested, which would allow the flow from exit channels to be precisely controlled. If an exit from a castellum was blocked off it would, by necessity, lead to a relative increase in supply to the other exits. If the main entrant to the castellum was restricted, the flow would have to be run off, further up the aqueduct. Precise control over the flow from a particular exit would allow those in charge of the castellum to direct supply to those areas with greatest demand.

However, recent research (Jansen \& De Haan 1996) suggests that the control of water through a castellum was not very precise. When the evidence of castella at Nîmes and Pompeii, as well as 
a site at Carthage (excavated by the present author in 1988) is examined, it can be demonstrated that there is no archaeological evidence for elaborate gate mechanisms. At the most, control was limited to the placing of a board across the exit channel. Each channel could thus be open or closed, but there was no means of controlling precisely how much water flowed in any direction. While it was possible for the authorities to prioritise demands in water supply based on the demand from the various exit channels, this could only be decided on the basis of an 'all or nothing' delivery.

Technically therefore, whilst the water would seem to flow liberally in the Roman city, the Romans did not have a great deal of control over the supply and were very susceptible to glut or shortage. Other measures such as wells and cisterns were necessary to ensure an essential year-round continuous supply of adequate volume.

\section{Rural Considerations}

So far this paper has adopted the viewpoint of the townsperson, but there are many reasons why the rural inhabitant of the urban hinterland might also see the need for an aqueduct. Brent Shaw argues (1984:132) that a town's water supply reflects consumption, in contrast to the countryside where water served the needs of production:

Large-scale monumental urban aqueducts, therefore, tend to be consequent upon a certain level of rural development and appear late in the urban/town centres that are generated by that agrarian growth (Shaw 1991:83).

Shaw bases this argument on textual evidence for the high construction costs of monumental aqueducts, and the archaeological evidence of some relatively large North African cities, such as Thuburbo Maius, where aqueducts were never developed.

The fundamental basis for these arguments is sound, but the detail requires some modification. Firstly, as Shaw himself describes, there was a wide range of technologies for water supply. Thomas and Wilson (1994:149) have suggested that in Italy aqueducts using terracotta pipes and wooden construction may have been relatively common for villa water supplies. These cheaper wooden structures would still be impressive in rural areas. They would certainly suggest that rural elites could be just as much involved in conspicuous consumption as their urban counterparts.

The majority of provincial aqueducts were built in the late first and second centuries AD. This is the period of greatest civic prosperity when we would most expect any city to be undertaking the more expensive public works. Considerable precision in dating has revealed that aqueducts are always one of the latest civic amenities to be built. The fact that these constructions are later than other public works may reflect the overall prosperity of the Roman economy as a whole, as much as local production and consumption.

Shaw's arguments thus allow the hypothesis of water supply as social control to stand. His work implies an image of the aqueduct as a symbol of consumption passing through a rural environment in which water was more an element of production. He highlights the aqueduct as a major, unnecessary, expense that was a reflection of Roman evergeticism rather than the avoidance of drought.

On a spiritual plane aqueducts may have had a further meaning. Many ancient religions believed in water spirits that inhabited springs, as the profusion of dedications throughout the Empire attests (Ferguson 1970:5-8). To a rural inhabitant living near a spring, its expropriation into an aqueduct could be seen as the extraction of a local deity's power, as well as the relocation of water needed for local fields. The provision of an aqueduct has been seen to suck that water spirit away from its natural 
domain into the city. The aqueduct could thus in itself be a sign of domination, removing the productive capacity from the rural hinterland, and enslaving a rural spirit in an urban fountainhead.

\section{Ownership of Water}

Some indication of the importance of territorial control of the lines of Roman aqueducts can be found in discussion of legal disputes. Shaw (1984:138) has shown how at least one ancient commentator, Agennius Urbicus, distinguished between Italy where legal disputes were concerned with illegal tapping of water supply, and Africa, where disputes were concerned with expropriation of water sources. This reflected different climatic conditions. In Italy, water flowed throughout the year and the problem was simply to obtain access to it. In Africa, a water course might only provide substantial quantities of water in the winter, or following major storms. The ability to redirect or control such floodwater determined its use. It would seem that the Romans themsel ves were aware that different provinces had different attitudes to water supply. Shaw $(1984,1991)$ has argued strongly that rich agricultural yields in Africa were due to indigenous rural water technologies, such as the management of run off. If the majority of water disputes in Africa were concerned with control of these sources, the resentment caused by the expropriation of one of these sources to supply a distant urban centre could have been considerable

Roman law allowed for the right to pass a water channel across someone else's land as a 'servitude': a right which could be purchased from a land owner (Crook 1967:149-150; Thomas \& Wilson 1994:148). Such rights can cause resentment as they persist even after property changes hands, and can seem like an affront to an owner's property rights. In Roman times they were often of ancient origin (Crook 1967:149).

The Pierre de Chagnon (CIL 13.1623) specifically forbids farming in the immediate vicinity of the Lyons (Gier) aqueduct. Construction of an aqueduct could, therefore, permanently remove agricultural land from local farmers and, in the case of substantial masonry channels without arches, sever one set of fields from another. The consequences for the redrawing of property boundaries can only be imagined.

Some of the complications arising from such water rights can be illustrated by an inscription from Spain of 87 BC (Robinson 1983). The Sosinetani had sold the right for a water channel to the Sallivenses (from Zaragossa), but the Allavonenses objected. C. Valerius Flaccus appointed a fourth local community to judge the dispute. The latter found in favour of the Sallivenses. The precise nature of the dispute eludes us, but control of the water supply and the land through which it ran was considered to be of vital public interest throughout the area.

\section{Conclusions}

The aim of this paper was to demonstrate that the water supply of the Roman world was controlled by the elite and was used for the social control of local populations. This hypothesis was supported with regard to the city of Rome by demonstrating the way in which Augustus and the emperors of the first century AD obtained more control of the water supply. The development of this power mirrored the control of other institutions used for social control of the population - the games, and the annona. Such specific evidence is not forthcoming from the provinces, however, it has been shown that the construction of provincial aqueducts often required the sanction of the emperor. The majority of provincial aqueducts were built by the provincial elite who controlled access to money and skills. 
In terms of the water supply, it has been shown that aqueducts were primarily used for elite purposes, and not for the benefit of the mass of the population. Technically the Romans were not able to control the aqueduct supply to meet specific fluctuation in demand. Aqueduct water was more commonly used for the purposes of evergeticism and luxuria. The two principal uses for urban monumental aqueducts were for public baths and municipal fountains. The former were the principal social centres of Roman towns, and the latter were dominated by massive backdrops displaying elite power and wealth.

Finally some consideration has been given to the impact of monumental aqueducts on the population outside the city. Legal disputes over water rights and the expropriation of agricultural land demonstrate that disruption of the rural social fabric was made subservient to the needs of the elite and the urban community.

Given this state of affairs it would seem to be a reasonable supposition that provincial elites used monumental aqueducts to support their own social order in the same way as the emperor did in Rome itself.

\section{Bibliography}

Akurgal, E. 1978. Ancient Civilisations and Ruins of Turkey. Ankara: TTK.

Aubert, P. 1974. Le Nymphee de Tipasa et les Nymphees Sepizonia Nord-Africains. Rome: Ecole Francaise de Rome.

Crook, J. 1967. Life and Law at Rome. London: Thames \& Hudson.

Ferguson, J. 1970. The Religions of the Roman World. London: Thames \& Hudson.

Garbrecht, G. 1991. Interdisciplinary co-operation in archaeological investigations. In Future Currents in Aqueduct Studies (ed. A. Trevor Hodge). Leeds: Francis Cairns, pp. 1-6.

Harlan, M. 1995. Roman Republican Moneyers and their Coins 63-44BC. London: Seaby.

Hauck, G. F. W. and Novak, R. A.1988. Water Flow in the castellum at Nimes. AJA, 92:393-407.

Hodge, A. Trevor 1983. Siphons in Roman aqueducts. PBSR, 51:174-221.

Hodge, A. Trevor 1984. How did Frontinus measure the quinaria? AJA, 88:205-216.

Hodge, A. Trevor 1992. Roman Aqueducts and Water Supply. London: Duckworth.

Jansen, G. and de Haan, N. (eds.) 1996. Cura Aquarum in Campania. Babesch.

Leveau, P. 1991. Research on Roman aqueducts in the past ten years. In Future Currents in Aqueduct Studies (ed. A. Trevor Hodge). Leeds: Francis Cairns, pp. 149-162.

Mansel, A. 1978. Side. Ankara: TTK.

Millar, F. 1977. The Emperor in the Roman World. London: Duckworth.

Robinson, J. S. 1983. The Tabula Contrebiensis: Roman law in Spain in the early first century BC. Journal of Roman Studies, 73:33-41.

Schwartz, H. 1981. Patterns of public and private water supply in North Africa. In Excavations at Carthage $\sigma$ (ed. J. Humphrey). Ann Arbor: University of Michigan, pp. 50-54.

Shaw, B. 1984. Water and society in the ancient Maghrib: technology, property and development. Ant Afr, 20:121-173.

Shaw, B. 1991. The noblest monuments, and the smallest things: wells, walls, and aqueducts in the making of Roman Africa. In Future Currents in Aqueduct Studies (ed. A.Trevor Hodge). Leeds: Francic Cairns, pp. 63-91.

Sherwin-White, A. N. 1966. The Letters of Pliny. Oxford: Clarendon.

Thebert, Y. 1987, Private life and domestic architecture in Roman Africa. In A History of Private Life I: From Pagan Rome to Byzantium (ed. P. Veyne). Belknap: Harvard, pp. 313-409.

Thomas, R. and Wilson, A. 1994. Water supply for Roman farms in Latium and South Etruria. PBSR, 62: 139-196. 